\title{
THE IDEA OF ACCESS TO JUSTICE: REFLECTIONS ON NEW ZEALAND'S ACCIDENT COMPENSATION (OR PERSONAL INJURY) SYSTEM
}

\author{
Tiho Mijatov \\ Tom Barraclough \\ Warren Forster*
}

The purpose of this article is to bring clarity in thinking about access to justice. We examine the idea of access to justice in the reform of personal injury law in New Zealand. Our findings are applicable to law reform in any area of law involving vulnerable people. After tracing the legal history of "access to justice," we isolate four separate conceptions of access to justice: equality before the law, a hybrid of judicial and nonjudicially focused conceptions that we have called the multifactorial conception, and conceptions emphasizing either judicial or non-judicial elements. We identify key features of each conception, and its strengths and weaknesses, in order to improve the quality of dialogue in law reform efforts. We conclude by considering the implications of our findings for law, which allow comparisons to be made between systems of law and law reform that aim to improve access to justice.

Cet article a pour but d'apporter des éclaircissements dans la réflexion concernant l'accès à la justice. Les auteurs y étudient l'idée de l'accès à la justice dans la réforme du droit du préjudice personnel en Nouvelle-Zélande. Leurs conclusions sont applicables à la réforme du droit dans n'importe quel domaine touchant les personnes sans défense. Après avoir reconstitué l'histoire juridique de l'" accès à la justice », les auteurs isolent quatre conceptions distinctes de cette notion : l'égalité en droit, une conception hybride comportant des éléments judiciaires et non judiciaires et des conceptions privilégiant soit les éléments judiciaires, soit les éléments non judiciaires. Les auteurs cernent les principales caractéristiques de chacune de ces conceptions, leurs forces et leurs faiblesses afin d'améliorer la qualité du dialogue dans les efforts de réforme du droit. Ils concluent en évoquant les répercussions de leurs conclusions pour le droit, ce qui permet l'établissement de comparaisons utiles entre les systèmes juridiques et une réforme du droit qui prétend favoriser l'accès à la justice.

\section{INTRODUCTION: WHY ACCESS TO JUSTICE?}

It is now axiomatic to even state that it is axiomatic that access to justice is under threat and that this is a notable failing of civil and criminal legal systems. But any solution to the access to justice problem depends on how the problem is defined. ${ }^{1}$ Isolating the nature and core assumptions behind access to

* Tiho Mijatov, Tom Barraclough, and Warren Forster, Research Fellows, Legal Issues Centre, Faculty of Law, University of Otago, Dunedin, New Zealand. This article expands upon a report written by the authors in July 2015 for Acclaim Otago and with financial support from the New Zealand Law Foundation. 
justice can "assist in formulating the right policy questions and in reducing the risk that unrealistic expectations will be created of the justice system" powerful theme in law reform." ${ }^{, 3}$ This article argues that, paradoxically, these unrealistic expectations can be devastating for access to justice, particularly for people with disabilities. It uses the example of New Zealand's lauded no-fault personal injury system - itself a pioneering access to justice response to the social problem of litigation for personal injury.

In 2015, the authors were responsible for a report into access-to-justice barriers faced by claimants to New Zealand's unique twenty-four-hour no-fault accident compensation system, ${ }^{4}$ which is administered by a Crown entity named the Accident Compensation Corporation $[\mathrm{ACC}] .^{5}$ The report followed a shadow report to the United Nations [UN] Committee on the Convention on the Rights of Persons with Disabilities [CRPD Committee] alleging that claimants to the ACC system were being denied access to justice in disputes arising out of the scheme. ${ }^{6}$ The report was also initiated in response to a government proposal to replace the District Court division tasked with resolving disputes arising from this scheme with a tribunal. The key concern of the authors was that the tribunal proposal would essentially reinforce existing mechanisms generating access-to-justice barriers, such as reliance on discretion, nominal informality, and absolutist approaches to the removal of delay. These would, perversely, exacerbate access-to-justice barriers regardless of the government's motivations.

The purpose of this article is to describe a shorthand that considers four "conceptions" of access to justice and then to use that shorthand to illustrate our access to justice exemplar - New Zealand's personal injury system. ${ }^{7}$ The conceptions are heavily drawn from the insightful work of previous scholars, but their primary function is not to reconceptualize access to justice thinking. Rather, it is to share a helpful "shorthand" for assessing access to justice in New Zealand's personal injury system. ${ }^{8}$ By using the four conceptions and reflecting on access to justice, we further illustrate that New Zealand does not have an "accident compensation" system in a restrictive sense but, instead, has a holistic

Lawrence M Friedman, “Access to Justice: Some Historical Comments” (2009) 37 Fordham Urb LJ 3 at 15.

2 Justice Ronald Sackville, "Some Thoughts on Access to Justice" (2004) 2 NZJPIL 85 at 111.

3 Roderick A Macdonald, "Access to Justice and Law Reform" (1990) 10 Windsor YB Access Just 287 at 290

[Macdonald, "Access to Justice and Law Reform"].

4 Acclaim Otago, "Understanding the Problem: An Analysis of ACC Appeals Processes to Identify Barriers to Access to Justice for Injured New Zealanders" (2015), online: Acclaim Otago <http://acclaimotago.org/wpcontent/uploads/2015/07/Understanding-the-problem-Access-to-Justice-and-ACC-appeals-9-July-2015.pdf> [Acclaim Otago, "Understanding the Problem"].

5 Accident Compensation Act, 2001 No 49, s 259 [2001 Act]; Crown Entities Act, 2004 No 115, s 7, Schedule 1.

6 Convention on the Rights of Persons with Disabilities, Doc A/61/611 (30 March 2007), art 34 (CRPD).

7 We note that the terms "conceptions" and "waves" have been used by other authors. See Roderick Macdonald, "Access to Justice in Canada Today: Scope, Scale and Ambitions" in Julia Bass, WA Bogart, \& Frederick H Zemans, eds, Access to Justice for a New Century: The Way Forward (Toronto: Law Society of Upper Canada, 2005) 19 and $\mathrm{n} 2$ for a further list of resources in the "enormous" literature [Macdonald, "Access to Justice in Canada Today"]; Macdonald is in turn cited in Jane Bailey, Jacquelyn Burkell, \& Graham Reynolds, "Access to Justice for All: Towards an "Expansive Vision" of Justice and Technology" (2013) 31 Windsor YB Access Just 181 at 184; and alternative usage of the term "waves" in Sackville, supra note 2 at 90, as used by Mauro Cappelletti \& Bryant Garth, eds, Access to Justice: vol 1: A World Survey (Alphen aan den Rijn: Sitjthoff and Noordhff, 1978).

8 We do not claim to have achieved the more arduous task of creating a formal taxonomy. See Emily Sherwin, "Legal Taxonomy" (2009) 15 Legal Theory 25. 
"personal injury system" that must be measured and judged accordingly. Since its inception in 1974, the system has evolved to recognize the shortcomings and failings of decisions to deploy various conceptions of access to justice. We conclude that serious policy failings can arise from a failure to appreciate the consequences of a given access-to-justice approach. "Legalism" must always have its consequences, ${ }^{9}$ including barriers as the authors have found them to be in the personal injury system: ${ }^{10}$ access to representation; access to law; access to evidence; "being heard" or a sense that justice has been done; and the advantages enjoyed by ACC as a repeat litigant. ${ }^{11}$

This article is structured as follows. We first explain New Zealand's accident compensation system for an international audience. We then explain the recent development of access-to-justice scholarship within New Zealand's ACC system and emphasize why it is a useful area for further investigation. From there, we acknowledge those whose efforts to categorize access to justice into waves laid the foundation for our conceptions. We then outline our own conceptions, which can be briefly described in the following terms: (1) access to justice as a synonym for equality or non-discrimination before the law in the manner of earlier human rights conventions; (2) a multi-factorial and wide account of access to justice that includes judicial and non-judicial formal institutions as well as informal institutions such as community organizations, disabled peoples' organizations, and even the application of accepted or contested norms of social justice; (3) a version that rejects courts as creators and resolvers of disputes reflecting their perceived failure to dispense justice and, therefore, emphasizing non-legal aspects of the second conception; and (4) a version that takes law as justice and regards access to law as access to justice, therefore regarding the courts as justice institutions essential to the application of legal rules and the dispensation of justice. We conclude by using the conceptions to show how a more nuanced understanding of access to justice can generate insights into aspects of New Zealand's personal injury system. We argue that careful attention must be paid to the personal injury system in a holistic sense if we mean to achieve access to justice for people suffering personal injury in New Zealand's lauded accident compensation scheme. ${ }^{12}$

\section{WHAT IS NEW ZEALAND'S ACCIDENT COMPENSATION SYSTEM?}

New Zealand has removed the right to sue at common law for personal injury. ${ }^{13}$ It has instead substituted a "no-fault" scheme that covers various kinds of personal injury, including injury caused by accident, by medical treatment, and by occupational gradual processes and diseases. ${ }^{14}$ It was instituted as a result of a trail-blazing report by the Royal Commission of Inquiry into Personal Injury, led by Sir

\footnotetext{
9 We refer to the "ethic of legalism" discussed in detail by Roderick Macdonald in his 1990 article. Macdonald, "Access to Justice and Law Reform," supra note 3.

10 Acclaim Otago, "Understanding the Problem," supra note 4 at 1-2.

11 Marc Galanter, "Why the 'Haves' Come Out Ahead: Speculations on the Limits of Legal Change” (1974) 9:1 Law \& Soc Rev 95.

12 See, e g, John G Farrell, “Administrative Alternatives to Judicial Branch Congestion” (2007) 27 Journal of the National Association of Administrative Law Judiciary 1 at 15.

13 See 2001 Act, supra note 5 at ss 133(5) and 317. For completeness, we note there are limited exceptions to this rule that are rare and beyond the scope of this article.

14 The authors dispute the appropriateness of this well-known label, but that is beyond the scope of the present article.
} 
Owen Woodhouse, who was then a judge of the Supreme Court (as the New Zealand High Court was called at the time). ${ }^{15}$ The report was completed in 1967 and is the product of various modes of thinking and social influences, including faith in the public service and bureaucratic administration, ${ }^{16}$ that deal with the social and economic problem of personal injury in New Zealand society. The scheme is now administered by a Crown entity corporation, known in New Zealand simply as "ACC", ${ }^{17}$ which is run by a chief executive answerable to a Board of Directors, which takes instruction from a dedicated minister for accident compensation in relation to government priorities. ${ }^{18}$ The scheme is funded from targeted levies and large investments, and its reserves are currently around NZ \$30 billion. ${ }^{19}$

Our thesis is that the conceptions of access to justice can be used to describe how the accident compensation system has changed in the way it conceives of what was, essentially, an access-to-justice problem in relation to the wider social problem of personal injury. The problem was succinctly defined by Woodhouse in the Royal Commission's report (Woodhouse Report):

The problem - One hundred thousand workers are injured in industrial accidents every year. By good fortune most escape with minor incapacities, but many are left with grievous personal problems. Directly or indirectly the cost to the nation for work injuries alone now approaches $\$ 50$ million annually.

This is not all. The same work force must face the grave risks of the road and elsewhere during the rest of every 24 hours. Newspapers up and down the country every day contain a bleak record of casualties.

The toll of personal injury is one of the disastrous incidents of social progress, and the statistically inevitable victims are entitled to receive a co-ordinated response from the nation as a whole. They receive this only from the health service. For financial relief they must turn to three entirely different remedies, and frequently they are aided by none.

The negligence action is a form of lottery. In the case of industrial accident it provides inconsistent solutions for less than one victim in every hundred. The Workers' Compensation Act provides meagre compensation for workers, but only if their injury occurred at their work. The Social Security Act will assist with the pressing needs of those who remain, provided they can meet the means test. All others are left to fend for themselves. Such a fragmented and capricious response to a social problem which cries

15 Owen Woodhouse, Compensation for Personal Injury in New Zealand: Report of the Royal Commission of Inquiry (Wellington: Government Printer, 1967) [Woodhouse Report].

16 See John R Martin, "Establishment of the Accident Compensation Commission 1973: Administrative Challenges" (2003) 34 VUWLR 249.

172001 Act, supra note 5.

18 See generally ACC, “Accountability Documents Archive," online: <http://www.acc.co.nz/about-acc/reports-andstrategy/accountability-documents-archive/index.htm>.

19 ACC, Annual Report 2015 (2015) at 39, online:

$<$ http://www.acc.co.nz/PRD_EXT_CSMP/groups/external_communications/documents/reports_results/2015annualrepor t.pdf $>$, which states that the total reserves portfolio is $\$ 31, \overline{4} 06$ million. 
out for co-ordinated and comprehensive treatment cannot be good enough. No economic reason justifies it. It is a situation which needs to be changed. ${ }^{20}$

The scheme was intended to minimize what we would today describe as access-to-justice barriers in relation to gaining compensation and rehabilitation for personal injury caused by accident. ${ }^{21}$ While initially industrially focused (contrary to Woodhouse's recommendations), the scheme widened its focus to non-work accidents ${ }^{22}$ and, subsequently, was extended to what was traditionally medical misadventure and occupational disease. Its fundamental precept was to avoid judicial processes entirely by removing the right to sue for damages at common law. Influenced in part by Terence Ison's Forensic Lottery, the privative ouster was justified by demonstrating that taking the money spent on the common law system and using it for the prevention of injuries and the rehabilitation of injured workers would save money overall and ensure a greater proportion of expenditure was available to victims of injury. ${ }^{23}$ This argument, based on administrative efficiency, would later become a key justification for an otherwise "collectivist" scheme. ${ }^{24}$ Once the political establishment had accepted community responsibility as a fundamental principle in dealing with personal injury caused by accidents, ${ }^{25}$ much of the principled opposition gave way to discussions about instrumental concerns: "[T]he fact that the two main political parties came to support the basic principles of the Royal Commission's proposals reduced the scope for debate." 26

The common law action for negligence causing personal injury is now almost entirely foreign to New Zealand law students. As described by Peter McKenzie, QC,

[i]t is difficult now, in the ACC era, to appreciate the extent to which common law litigation in personal injury cases occupied the legal profession, the Courts and the trade unions. Most legal offices had a significant "common law" practice involved in the formulation and settlement of personal injury claims. Some 90 percent of the claims were settled out of Court. Those which did go to trial were handled by advocates who generally combined this area of practice with the conduct of jury trials in criminal cases. Personal injury dominated the law of negligence. Most of the case law in negligence had arisen out of personal injury litigation. The advent of the ACC system required a new

20 Woodhouse Report, supra note 15 at 19 , para 1.

21 We note Palmer's categorization of them in the context of access to justice barriers in 1985. Geoffrey Palmer, "The Growing Irrelevance of the Civil Courts" (1985) 5 Windsor YB Access Just 327 at 332.

22 See the discussion in Don Rennie, "Administering Accident Compensation in the 1980s" (2003) 34:2 VUWLR 329.

23 Peter McKenzie "The Compensation Scheme No One Asked For: The Origins of ACC in New Zealand" (2003) 34(2) VUWLR 193 at 197, noting also that the "contribution of Ison to the comprehensive scheme advocated by the Woodhouse Commission should not be overstated. ... the basic shape of the proposals in the Report had already been formulated before Sir Owen encountered Professor Ison's text." Terence G Ison, The Forensic Lottery (London: Staple Press, 1967). Woodhouse Report, supra note 15, at 21-22.

24 Geoffrey Palmer, Compensation for Incapacity (Wellington: Oxford University Press, 1979) at 205; see also Part 1(II) at 13-22 for an intriguing description of the situations Woodhouse's report sought to remedy: "The Mysterious Accident on the Otoko Hill," which concludes: "The trial was an Alice-in-Wonderland fantasy" (at 22).

25 Ibid at 205.

26 Ibid at 83 . 
approach to the teaching of negligence in New Zealand law schools. It was difficult in compiling Tort in Transition, a casebook produced in 1976, to illustrate the principles of negligence by reference to other than personal injury cases. ${ }^{27}$

Such a description may be entirely commonplace to international common law readers, but the fact that it even has to be described in the above terms - as a foreign concept to New Zealand law students - may illustrate to an international audience how successful the scheme has been in removing the common law action from New Zealand society.

We note, however, that removing the common law action is not to be conflated with removing fault and dispute from the lives of injured New Zealanders. Despite the scheme's ambition to remove judicial processes, it has always retained dispute resolution mechanisms in various forms. ${ }^{28}$ Further, we argue (later in this article) that the failure of these judicial mechanisms to explicitly ascribe fault or blame to third parties or to ACC itself has led to an outgrowth of accountability and learning mechanisms towards a holistic "personal injury system." Generally speaking, across the various incarnations of the scheme, there has been a first-instance, merits-based review available against a decision by ACC as well as an appeal against this review to a judicial figure with wide jurisdiction. ${ }^{29}$ These processes vary in their orientation between investigative or adversarial procedures and commonly employ a mixture of both, although they seldom include viva voce evidence and have never included a jury. There is a right of appeal to the High Court of New Zealand, generally only on questions of law of public importance, and a final right of appeal to the Court of Appeal against any High Court decision.

The broad scope of the scheme as an extra-judicial access-to-justice measure has been progressively limited in favour of a legalistic focus. In the 1982 enactment, "personal injury by accident" was given a broad extending definition, which "includes the physical and mental consequences of any such injury or of the accident." ${ }^{\prime 30}$ This test can be contrasted with later tests, which rely on a legal concept of "causation" - that is, that an injury has been "caused by" an "accident." 31 There has been an increasing "drift to legalism" $" 32$ in an effort to inject objectivity, consistency, and accountability with a view to

27 We suggest the title of McKenzie's article in describing the ACC as a scheme "no one asked for" is not reflective of its content, which generally praises the ACC system and illustrates numerous statements and social influences that suggest there were calls for a compensation scheme as devised by Woodhouse. McKenzie, supra note 23 at 195.

28 Woodhouse Report, supra note 15 at 126-127.

29 The word "decision" is itself a statutory term, whose definition has varied between enactments. See, e g, the 2001 Act , supra note 5, s 6 "decision"; Accident Insurance Act, 1998 No 114, s 13 "decision"; Accident Compensation Act, 1982 No 181, s 2 "decision" [1982 Act].

301982 Act, ibid, s 2: "personal injury by accident" [emphasis added].

312001 Act, supra note 5, s 20(2); s 20(2)(a) provides the "caused by" test for cover; and s 25 defines "accident." See also the variety of causation tests present in ss $6,25,26,30,32$. The leading case law on causation is Accident Compensation Corporation v Ambros, 2007 NZCA 304, [2008] 1 NZLR 340 at para 60ff. "[P]ersonal injury" was given an expansive statutory definition in Allenby $v$ H, 2012 NZSC 33, [2012] 3 NZLR 425.

32 A term used in the Woodhouse Report, supra note 15 at 127: "[I]nformal and simple procedure should be the key to all proceedings within the jurisdiction of the Board. Applications should not be made to depend upon any formal type of claim, adversary techniques should not be used, and a drift to legalism avoided." 
reducing what are perceived to be growing and unsustainable costs. ${ }^{33}$ This legalism, with the consequential changes in bureaucratic culture and incentives, has contributed to increased litigation through the dedicated dispute resolution procedures under the 2001 Act. $^{34}$ The ACC scheme, as administered by the government of New Zealand and ACC, is itself an access-to-justice mechanism, ${ }^{35}$ but, oddly, it is only recently that attention has turned to access to justice for those seeking to access that mechanism.

\section{ACCESS TO JUSTICE SCHOLARSHIP RECENTLY (RE)INTRODUCED TO NEW ZEALAND'S ACC SYSTEM}

Despite (or perhaps because of) the fact that it is a scheme directed to removing the need for litigation, New Zealand's ACC system has only recently been reconsidered in relation to access to justice. ${ }^{36}$ ACC is generally thought to remove considerations of fault from disputes and, therefore, any litigation. Hence, in New Zealand and abroad, ACC has been given its "no-fault" label. ${ }^{37}$ Though excellent, there are three relatively recent special issues on the ACC scheme by New Zealand law journals that do not feature any dedicated discussion on the specific operation or interpretation of the dispute resolution provisions, on the operation of its institutions, or on access to justice under the system. ${ }^{38}$ Instead, they focus primarily on substantive matters of cover and entitlements available to litigants and the substantive outcomes of judicial decisions. Entitlements are primarily analyzed in relation to historic entitlements under the scheme (which has now operated for more than forty years)

33 See an editorial piece by then chairman of the Board of Governors for the Accident Compensation Corporation, who was tasked with remedying a $\$ 4.8$ billion annual loss in part by "limit[ing] its services to those it was legislatively required to provide [sic].” John Judge, “Only Years of Vigilance Will Solve ACC Debt Crisis,” New Zealand Herald (8 July 2010), online: <http://www.nzherald.co.nz/nz/news/article.cfm?c_id=1\&objectid=10657185>. There have been other historic deficits in the scheme with sharp associated increases in levy payments of, at the most, 265 percent. Rennie, supra note 22 at 341.

34 Honorable Chester Borrows, Minister for Courts, "Further Improvements to Tribunals Announced," Press Release (24 June 2014), online: $<$ https://www.beehive.govt.nz/release/further-improvements-tribunals-announced $>$. See also Office of Hon Chester Borrows, "Courts and Tribunals Enhanced Services Legislation Bill Questions and Answers," Press Release (24 June 2014), online: <https:/www.beehive.govt.nz/sites/all/files/40624_CATES_Q_A.pdf>. 2001 Act, supra note 5, Part 5 and associated transitional provisions in Part 11: "The number of appeals received each year ... exceeds the number being resolved in that year. The age of cases is high and rising. The average age of ACC appeals currently before the District Court registry is 695 days. Changes being made are intended to reduce the time it takes to finish cases to around 250 days."

35 Administrative compensation schemes have long been discussed as alternatives to civil litigation in access to justice literature, and early examples include a theory proposed by Oliver Wendell Holmes, Jr, "Trespass and Negligence" (1880) 14 Am L Rev 1 at 12 and then the enactment of Germany's Accident Insurance Act in 1884. For a recent example, see Macdonald, "Access to Justice in Canada Today," supra note 7 at 73.

36 Although we note the access to justice lens applied in 1985 by Geoffrey Palmer, supra note 21 at 332 : "[T]he civil litigation associated with the law of negligence was an important part of what was wrong with personal injury law."

37 Ibid at 333: Palmer describes how in the New Zealand and Australian reports giving rise to scheme proposals "[ $\mathrm{t}] \mathrm{he}$ principle of fault was not found to be socially relevant. It screened out citizens from compensation who were frequently innocent and greatly in need of help."

38 These issues are (2003) 34:2 VUWLR; (2004) 35:4 VUWLR; (2008) 1 NZ L Rev. 
and, by contrast, with other entitlements available under New Zealand's separate social welfare regime. $^{39}$

Access to justice has assumed prominence in recent years since New Zealand ratified the UN $C R P D .^{40}$ The authors were responsible for a shadow report to the UN CRPD Committee, which alleged that ACC claimants were being deprived of access to justice in their dealings with ACC. ${ }^{41}$ In August 2014, the UN CRPD Committee met in Geneva, Switzerland, to question the New Zealand government on its compliance with the CRPD. The government's official report was examined by reference in part to this shadow report. ${ }^{42}$ The committee elected to focus on Article $13,{ }^{43}$ which provides rights to "effective access to justice" and concluded that "persons who have suffered injuries are concerned over the lack of access to justice in pursuing their claims," and it gave detailed examples. ${ }^{44}$ These examples correspond well to the various conceptions of access to justice that we will consider later in this article. Specific concerns ranged from legal aid and inadequate financial assistance for litigants, ${ }^{45}$ to a lack of consultation on proposed privative restriction from access to the District Court, ${ }^{46}$ to the need for a human rights-centred approach in ACC scheme administration and in dispute resolution. ${ }^{47}$

More recently, in July 2015, the New Zealand government deferred its plans to abolish access to the District Court for appeals in the ACC dispute resolution system in favour of a new tribunal. This response coincided with the publication of another report by the authors that found the barriers to accessing justice in ACC disputes were significant. The report concluded that a new tribunal would most likely be ineffective at reducing these barriers and would instead be likely to exacerbate the problem. ${ }^{48}$ This conclusion was supported by a majority of public submitters once the government opened the proposal for public submission, ${ }^{49}$ and we now suggest that it was based upon misunderstandings of what

39 From the inception of the ACC scheme, Woodhouse agreed there was no logical foundation for excluding personal injury caused by illness or congenital disability from the scheme. For more, see discussion in Palmer, supra note 24. See also a reiterated commitment to this position by Woodhouse as a member of the Law Commission, discussed in Kenneth Keith, "The Law Commission's 1988 Report on Accident Compensation" (2003) 34:2 VUWLR 293.

40 Convention on the Rights of Persons with Disabilities Act, 2008 No 64. CRPD, supra note 6.

41 Acclaim Otago, "The Costs of Paradigm Change: Access to Justice for People with Disabilities Caused by Personal Injury in New Zealand" (2014), online: <http://acclaimotago.org/wp-content/uploads/2014/08/Acclaim-NZ-ShadowReport-for-UN.pdf $>$ [Acclaim Otago, "The Costs of Paradigm Change"].

42 New Zealand, "Implementation of the Convention on the Rights of Persons with Disabilities," Doc CRPD/C/NZL/1 (2013), online: <http://tbinternet.ohchr.org/_layouts/TreatyBodyExternal/Countries.aspx?CountryCode $=$ NZL\&Lang $=\mathrm{EN}>$.

43 UN Committee on the Rights of Persons with Disabilities, "List of Issues in Relation to the Initial Report of New Zealand," Doc CRPD/C/NZL/Q/1 (2014) at para 14, online: <http://tbinternet.ohchr.org/_layouts/TreatyBodyExternal/Countries.aspx?CountryCode=NZL\&Lang=EN.

44 UN Committee on the Rights of Persons with Disabilities, "Concluding Observations on the Initial Report of New Zealand," Doc XII CRPD/C/NZL/CO/1 (3 October 2014) at para 23 [UN Concluding Observations] [emphasis added].

45 Acclaim Otago, "The Costs of Paradigm Change," supra note 41 at 13.

46 Ibid at 11.

47 Ibid at 4-11, 22-23.

48 Acclaim Otago, "Understanding the Problem," supra note 4 at 1-4.

49 Public submissions have been collated by the Ministry for Business, Innovation and Employment and are available online: $<$ http://www.mbie.govt.nz/info-services/employment-skills/legislation-reviews/proposed-accident-compensationappeal-tribunal/submissions-received $>$. 
conception of access to justice was being applied, or needed to be applied, in the context of the CRPD and the policy orientations of the ACC scheme. New Zealand's personal injury system and its treatment of people with disabilities is therefore a practical and recent medium by which our message can be conveyed - namely, that there are different conceptions of access to justice being used by different components of New Zealand's personal injury system that require close reflection. Our conceptions are intended to provoke discussion and contribute to an increased clarity of communication about access-tojustice concepts as New Zealand reconsiders how its ACC scheme operates.

\section{DISCUSSION OF THE CRPD AND ACCESS TO JUSTICE IN THE PERSONAL INJURY SYSTEM}

An obvious framework for reform is the $C R P D$, and there are already striking similarities between the $C R P D$, the access-to-justice literature, and the social, collectivist orientation of the ACC scheme. The CRPD was unanimously adopted by the UN General Assembly in 2006, and it "has broken a number of records. Its negotiations were the fastest in the history of the UN human rights treaties. ... In addition, the number of signatories on the first day of the CRPD's opening for signature was the highest in UN history ... These figures suggest a significant consensus on the disability-related definitions, problems, and solutions put forward by the CRPD. ${ }^{, 50}$ Like access-to-justice scholarship, New Zealand's personal injury system is ostensibly directed towards mitigating the socio-political and bio-medical barriers faced by people with disabilities. ${ }^{51}$ The ACC legislation is already directed towards removing the impact of vocational, medical, and psychological impairments and barriers to enable a person to return to the workforce. ${ }^{52}$ The $C R P D$ is predicated on similar grounds and recognizes the insights of the social model of disability. ${ }^{53}$

The social model of disability recognizes the large extent to which the experience of "being disabled" is generated by society's own intolerance of human diversity: "The benefits of all social approaches are that they shift attention away from individuals and their physical or mental deficits to the ways in which society includes or excludes them." ${ }^{, 54}$ Scholars have illustrated how liberalism favours an idealized "normal" archetype that disadvantages people who diverge from that norm. ${ }^{55}$ The convention adopts

50 Teodor Mladenov, "The UN Convention on the Rights of Persons with Disabilities and Its Interpretation" (2013) 7 European Journal of Disability Research 69 at 72.

51 We acknowledge Macdonald's discussion ("Access to Justice and Law Reform," supra note 3 at $298 \mathrm{ff}$ ) of how the "barrier" metaphor reflects a problematic orientation towards the ethic of legalism. We also acknowledge that the barrier metaphor may be objectionable from a disability perspective. No offence is intended. We continue to use the barrier metaphor here for convenience and to illustrate a parallel orientation between the systems.

52 Although the authors maintain it does not go far enough and the vocational independence process results in victim blaming in a similar manner to that discussed in Tom Shakespeare, Nicholas Watson \& Ola Abu Alghaib, "Blaming the Victim All Over Again: Waddell and Aylward's Biopsychosocial (BPS) Model of Disability” (2016) 36(4) Critical Social Policy 1.

53 Paul Harpur, "Embracing the New Disability Rights Paradigm: The Importance of the Convention on the Rights of Persons with Disabilities" (2012) 27 Disability and Society 1 at 3.

54 See Shakespeare's historical discussion of the social model in Tom Shakespeare, Disability Rights and Wrongs Revisited (Milton Park, UK: Taylor and Francis, 2013) at 12.

55 See discussion of these scholars in ibid at 90. 
"person-first" terminology. ${ }^{56}$ Such terminology is intended to emphasize that "people with disabilities" are "people first," defined by their personhood, and to "express the common humanity which disabled people share." "57 Equally, other communities may reject person-first language because "people with impairment are disabled by society, not by their bodies. The phrases 'people with disabilities' or worse, 'people with physical disabilities' become unacceptable because they imply that 'disabilities' are individual deficits." 58 Our view is that the ACC scheme falls well short of the CRPD's standards and that there is an undue and outdated focus on physical impairment and individual deficit. However, for present purposes, there is an unmistakeable parallel orientation between them in the sense that they focus at a high level on the experiences and well-being of people with disabilities.

The personal injury system is an appropriate exemplar from an international perspective because it is held out as a system to aspire to on the basis of its rehabilitation entitlements, including social rehabilitation, and ostensibly superior income replacement at 80 percent of pre-injury earnings. ${ }^{59}$ Australia has recently begun to implement its federal disability schemes, ${ }^{60}$ which have clear parallels with ACC, and we suggest that they are likely to suffer the same access-to-justice issues unless they are considered carefully.

Analysis and improvement of a system that is supposed to minimize the effect of barriers facing people with disabilities is also likely to assist people within the wider justice system. ACC accepted approximately 1.8 million claims in 2014-2015 in relation to New Zealand's population of approximately 4.5 million people. ${ }^{61} \mathrm{ACC}$ claims this "equates to $30.5 \%$ of New Zealanders receiving compensation or rehabilitation services." "62 Further, it seems self-evident that the nature of accidents is that they tend to occur unexpectedly (which is not to say they cannot be prevented), meaning every New Zealander has a stake in the personal injury system either by themselves or as part of a community. Despite ACC's favourable depiction of claim rates and the support it provides, New Zealand's 2013 census identified 320,000 New Zealanders with long-term disabilities caused by accident or injury. ${ }^{63}$ According to public statements by the Minister for ACC in August 2014, ACC was "able to decrease the amount of people on long-term [ACC] benefits from 11,000 to 8,000 " people. ${ }^{64}$ While there may be good reasons for the gap between those numbers, there is a potentially large group of people who are not being provided with support for their disability by ACC, which is charged with doing so.

\footnotetext{
Harpur, supra note 53.

See discussion in Shakespeare, supra note 54 at 19.

Ibid.

2001 Act, supra note 5, ss 79, 81.

60 National Rural Health Alliance "From the Journal Associates: The National Disability Insurance Scheme (NDIS)" (2013) 21:1 Australian Journal of Rural Health 54.

61 ACC, supra note 19 at 9.

62 Ibid.

63 Defined by Statistics New Zealand as six months or longer, online: $<$ http://www.stats.govt.nz/browse_for_stats/hea1th/disabilities/DisabilitySurvey_HOTP2013/Definitions.aspx>. Statistics New Zealand, 2013 New Zealand Disability Survey (2014), at 6.02 (cause of impairment for disabled people (numbers), by age group and sex), online: $<$ http://www.stats.govt.nz/browse_for_stats/health/disabilities/DisabilitySurvey_HOTP2013/Tables.aspx>.

64 Adam Bennett, "Workers and Bosses Lose out to Motorists in ACC Levy Cuts," New Zealand Herald (6 August 2014), online: $<$ http://www.nzherald.co.nz/nz/news/article.cfm?c_id=1\&objectid=11304503>.
} 
It is well established that injured people or people with disabilities are particularly vulnerable to experiencing problems in seeking access to justice. They "tend to have high rates of intersection with civil legal problems" ${ }^{65}$ and are certainly "more likely to have a legal problem (relative to those who do not have a disability). ${ }^{, 66} \mathrm{New}$ Zealanders who have received decisions from ACC to decline their claim report similar experiences, ${ }^{67}$ and the consequences of workplace accidents have social and economic consequences that "ripple out" into the community ${ }^{68}$ New Zealand's no-fault personal injury system is directed towards nationalizing and distributing the costs of injury, so it also means interacting with a large number of government officials and institutions. People with disabilities also face pervasive negative perceptions and attitudes, and the Australian Human Rights Commission has noted such attitudes "often result in people with disabilities being viewed as unreliable [or] not credible." ${ }^{199}$ This can be amplified by attitudes or conceptual models that result in victim blaming or the perception that a person's disability experience is out of proportion to their biomedical impairment. ${ }^{70}$ ACC itself is responsible for prominent media engagement around fraud. ${ }^{71}$

Authors such as Paul Harpur now suggest that the CRPD has created a "disability rights paradigm," which goes beyond previous human rights instruments. ${ }^{72}$ It introduces provisions designed to ensure that people with disabilities can make interventions to defend their $C R P D$ rights. ${ }^{73}$ Assessing the various conceptions of access to justice in relation to the CRPD means we can assess the strengths and flaws of various conceptions of access to justice against the needs of some of the most vulnerable people in our society and the high water mark for international human rights instruments. Our discussion of ideas in a personal injury context, with a disability rights emphasis, is therefore intended to be illuminating rather than limiting.

Despite the international support for the $C R P D$, the mere fact of its existence represents international agreement that there is still much to be done in facilitating access to justice for people with disabilities.

65 Canadian Forum on Civil Justice, "The Cost of Justice: Weighing the Costs of Fact and Effective Resolution to Legal Problems" (2012) at 3; see also KM Research and Consultancy, "Access to Justice: A Review of the Existing Evidence of the Experiences of Adults with Mental Health Problems, UK Ministry of Justice, Research Series 6/09 (May 2009) at $7,19,26$.

66 Christine Coumarelos et al, Legal Australia-Wide Survey, Law and Justice Foundation of New South Wales, Access to Justice and Legal Needs, vol 7 (August 2012), cited in Australian Productivity Commission, "Access to Justice Arrangements," Inquiry Report 1(72) (5 September 2014) at 97 [LAW Survey].

67 Acclaim Otago, "Crying for Help from the Shadows: The Real Situation in New Zealand; A Summary of Survey Data" (2014), online: <http://acclaimotago.org/wp-content/uploads/2014/08/ACCLAIM-Otago-Survey-Data-for-UNCRPDAug-2014.pdf $>$ [Acclaim Otago, "Crying for Help from the Shadows"].

See the qualitative study by Mary Adams et al, "Aftermath: The Social and Economic Consequences of Workplace Injury and Illness" (Department of Labour and the Accident Compensation Corporation, 2002) at 10-11.

69 Australian Human Rights Commission, "Equal before the Law: Towards Disability Justice Strategies (2014) at 8.

70 See Shakespeare, supra note 54.

71 See, e g, ACC, "Reporting Fraud," online: <http://www.acc.co.nz/making-a-claim/ECI0058>; ACC, "Home Detention for Ashburton Man Who Presented Himself as Wheelchair-Dependent to Prolong ACC Cover," Press Release (14 February 2014), online: <http://www.acc.co.nz/news/WPC133354>; Mike Barrington, “ACC Investigators Save \$22.7m in NZ," The Northern Advocate (5 August 2014), online: <http://www.nzherald.co.nz/northernadvocate/news/article.cfm?c_id=1503450\&objectid=11304129>.

72 Harpur, supra note 53.

73 Ibid at 4-5. 
We argue that the convention is an example of a new approach to understanding access to justice, characterized by "the emergence of the full panoply of institutions and devices, personnel and procedures, used to process or prevent disputes in modern societies."74 The next part of this article will illustrate how our shorthand conceptions differ from previous authors' important work in categorizing access-to-justice concepts using metaphors such as waves. We will then explain our simple shorthand for access to justice ideas before using them to describe New Zealand's personal injury system.

\section{PREVIOUS CONCEPTUALIZATIONS OF ACCESS TO JUSTICE ARE USEFUL, BUT WE DO NOT SEEK TO DEVELOP THE "WAVES" METAPHOR}

Before describing our shorthand, we note that there has been significant scholarship on the history of access to justice, which we will not comprehensively revisit here. In the second half of the twentieth century, there has been a move from justice to "access to justice." Authors such as Roderick Macdonald have attributed this to a "meta phenomenon" in law that displaces ends with means: "justice" with "access." 75 Something that might be called an access-to-justice movement gained traction in the $1960 \mathrm{~s}^{76}$ and had evolved by 1978 with the publication of a report describing access to justice as a "worldwide movement to make rights effective." 77

There have been several attempts to categorize the "waves" of "access to justice," which have variously described three, ${ }^{78}$ four, ${ }^{79}$ and five waves. ${ }^{80}$ The metaphor was originally developed by Mauro Cappelletti and Bryant Garth ${ }^{81}$ and then taken further by Macdonald to describe a wider justice system. ${ }^{82}$ As has been noted by previous scholars, the differences between these descriptions can be explained by the breadth of the system that is being described. ${ }^{83}$ What emerges is that (1) conceptions of access to justice have changed over time and (2) the dominant conception at any given time has correlated with the goals the movement then pursued. ${ }^{84}$ Regardless of the waves by which it is characterized, or who is doing the characterizing, there appears to be general conceptual agreement that while the starting point

74 Sackville, supra note 2 at 90.

75 Macdonald, “Access to Justice and Law Reform,” supra notes 3; Macdonald, “Access to Justice in Canada Today,” supra note 7.

76 Sackville, supra note 2 at 88.

77 Cappelletti \& Garth, supra note 7.

78 Cappeletti \& Garth, supra note 7; Sackville supra note 2.

79 Christine Parker, Just Lawyers: Regulation and Access to Justice (Oxford: Oxford University Press, 1999) at 31; Kim Economides "2002: A Justice Odyssey" (2003) 34(1) VUWLR 1.

80 Macdonald, "Access to Justice in Canada Today," supra note 7.

81 Cappelletti \& Garth, supra note 7.

82 See a refinement of the account of these three waves in Roderick A Macdonald, "Access to Civil Justice" in Peter Cane \& Herbert M Kritzer, eds, The Oxford Handbook of Empirical Legal Research (Oxford: Oxford University Press, 2010) 492 at 503-509.

83 Patricia Hughes, Law Commissions and Access to Justice: What Justice Should We Be Talking About? (2008) 46(4) Osgoode Hall LJ at 780. Another scholar has described the waves as "phases". See Catherine Orchanda, Access to Justice: The Contribution of Drafters (MA thesis, Institute of Advanced Legal Studies, University of London, 2013) ch 2.

84 Christine Coumarelos et al, Legal Australia-Wide Survey, vol 7 (Law and Justice Foundation of New South Wales, Access to Justice and Legal Needs, August 2012) at 3-5. 
for access to justice was providing access to the courts and equality before the law for individuals, the end point of the access-to-justice journey will be a broader integrated justice system that is directed towards the production of just outcomes. This end point has been characterized by some Canadian scholars as an "expansive vision" of "deliverables" to "beneficiaries" and incorporating all of Macdonald's five waves (further reconceptualizing them as "clusters"). ${ }^{85}$

We will not attempt to re-characterize previous scholars' ideas into a different metaphorical set; that work has already been admirably accomplished. Instead, we share a shorthand we have found useful, developed as a result of reading these authors' work. This shorthand is primarily organized by high-level reflections on the idea underpinning each "conception" as we understand them. The short point is that we seek to avoid a historical narrative in favour of distinguishable access-to-justice approaches. We acknowledge that this notion sounds abstract at this stage, but we will supplement our shorthand with examples derived from the personal injury system and then use it to describe this system. A key purpose of publicizing our approach is so that it can be publicly tested, and we welcome any critical analysis.

Chronological arrangement can be useful because in certain respects the waves of access to justice can be seen as reflections on the shortcomings of previous waves. One recent article put it this way: "[T] he project of the twentieth century was getting people into courts. The question for the twenty-first is what to do with all who became eligible to enter. $" 86$ These categories are worth considering in order to learn from that experience. It would be misguided now, and ahistorical, to view the entire access-tojustice movement in modern times as a project to increase the number of people using formal judicial institutions such as civil courts; the movement is more nuanced than that. In a general sense, policy and legislation responded to the lack of access to legal institutions and legal representation by people with limited financial resources by providing for legal aid. Access to justice by group and collective interests has been enabled by loosening standing requirements in many areas of the law, by broadening the scope for judicial review, and by recognizing group rights in legislation. ${ }^{87}$ Certainly, there is also a panoply of institutions including various commissioners, ${ }^{88}$ authorities, ${ }^{89}$ ombudsmen, ${ }^{90}$ as well as the Auditor-

85 Jane Bailey, Jacquelyn Burkell \& Graham Reynolds, “Access to Justice for All: Towards an "Expansive Vision" of Justice and Technology" (2013) Vol 31, No 2, Windsor YB Access Just 181 at 184 [Bailey, et al, "Access to Justice for All'], citing Action Committee on Access to Justice in Civil and Family Matters, Access to Civil and Family Justice: A Roadmap for Change (Ottawa: Action Committee on Access to Justice in Civil and Family Matters, 2013, online: Canadian Forum on Civil Justice <http://www.cfcjfcjc.org/sites/default/files/docs/2013/AC_Report_English_Final.pdf>

86 Judith Resnik \& Dennis E Curtis Representing Justice: Invention, Controversy and Rights in City-States and Democratic Courtrooms (New Haven: Yale University Press, 2011) at 306.

87 Including the New Zealand Bill of Rights Act, 1990 No 109, s 15 ("in community with others") and s 20 (right to enjoy minority culture).

88 E g, Health and Disability Commissioner Act, 1994 No 88 (Health and Disability Commissioner); Human Rights Act, 1993 No 82, Part 1 (Human Rights Commission); Privacy Act, 1993 No 28, Part 3 (Privacy Commissioner); Transport Accident Investigation Commission Act, 1990 No 99, Part 2 (Transport Accident Investigation Commission); Children's Commissioner Act, 2003 No 121, Part 2 (Children's Commissioner); New Zealand Public Health and Disability Act, 2000 No 91, s 59A (Health Quality and Safety Commission).

89 E g, 1982 Act, supra note 29, s 103-110 (Accident Compensation Appeal Authority); Social Security Act, 1964 No 136 , s 12A (Social Security Appeal Authority); Civil Aviation Act, 1990 No 98, Part 6A (Civil Aviation Authority); Independent Police Conduct Authority Act, 1988 No 2 (Independent Police Conduct Authority); Employment Relations Act, 2000 No 24, Part 10, s 156 (Employment Relations Authority). 
General, ${ }^{91}$ all of whom investigate disputes in relation to legal criteria from outside the courts or direct parties towards non-judicial or non-legal resolution.

Another key insight by scholars such as Macdonald is that the "waves" metaphor, however conceptualized, has meant "there is a persistent focus on access to institutionalized dispute resolution in the successive waves" - this focus "has not receded; rather, it has continued to dominate access to justice thinking and reform projects. ${ }^{, 92}$ What we found is that developing a shorthand for different highlevel understandings of "access to justice" allowed us to generate debate based around which institution (understood expansively, including non-legal community institutions) is directed towards which aspect of "access to justice."

The four conceptions we proceed to outline do share a feature of chronological waves, in that each may be used to provide a conceptual response to another, but this can occur in a non-linear way. Advocates for access to justice can often find themselves (as we did) facing arguments that were long ago dismissed in an earlier movement - for example, by suggesting that general rights of appeal are sufficient to dispose of access-to-justice concerns. The fact that "access to justice" is capable of many conceptions means that we do ourselves a disservice if we do not attempt to justify why a given conception is the preferred one at any given time or for a particular purpose. We will also argue that conflation of the conceptions of access to justice can lead to negative policy implications for peoples' ability to gain justice through legal institutions. Our use of conceptions is not to describe the access-tojustice journey, nor the tools to get there, but, instead, what we mean when we are talking about access to justice.

\section{FOUR CONCEPTIONS OF ACCESS TO JUSTICE}

Using ideas as our yardstick, we considered four distinct conceptions of access to justice. ${ }^{93} \mathrm{We}$ recognize that in each jurisdiction, some of these can be located at one or more points in history or within a system. Our shorthand categories can be briefly described as follows: (1) access to justice as a synonym for equality or non-discrimination before the law in the manner of earlier human rights conventions; (2) a multi-factorial and wide account of access to justice that includes judicial and nonjudicial formal institutions as well as informal institutions such as community organizations, disabled peoples' organizations, and even the application of accepted or contested norms of social justice; (3) a version that rejects courts as creators and resolvers of disputes, reflecting their perceived failure to dispense justice and therefore emphasizing non-legal institutions; and (4) a version that takes law as justice and regards access to law as access to justice, therefore regarding the courts as justice institutions essential to the application of legal rules and the dispensation of justice. We will discuss each in turn by reference to New Zealand's personal injury system.

90 E g, Ombudsman Act, 1975 No 9 (Banking Ombudsman Scheme Limited), online: $<$ http://www.bankomb.org.nz>; (Insurance and Financial Services Ombudsman Scheme Incorporated), online: $<$ http://www.iombudsman.org.nz $>$.

91 Public Audit Act, 2001 No 10, Part 2 (Controller and Auditor General).

92 Janet Mosher, "Lessons in Access to Justice: Radicalized Youths in Ontario’s Safe Schools" (2008) 46:4 Osgoode Hall LJ 807 at 817.

93 We recognize that other scholars have also used the language of "conceptions" when describing ideas of access to justice, including Macdonald's “waves." See Bailey, et al, “Access to Justice for All” supra note 85 at 184. 


\section{A. The First Conception: Equality Before the Law}

Access to justice as equality before the law emphasizes the importance of "equal access to justice," which should "mean that different groups in a society would have similar chances of obtaining similar resolutions to similar kinds of civil justice problems." enjoy equality before the law. This principle in turn derives from the notion that the foundations of justice rest on recognition by the state of the values of human dignity and political equality." 95 This conception is closely linked to "wider human rights concerns and the need to promote equality and fairness. ${ }^{" 96}$ This rationale means that access to justice as equality before the law can be described as a democratic account since, "in a democratic community, people are entitled to make claims on one another on the basis of their equality." ${ }^{, 97}$ Every person's equality with others means that protecting one's interests need not come down to appealing to self-interest or the benevolence of others alone. ${ }^{98}$ This conception of access to justice appears difficult to criticize for who could be against dignity, political equality, and fairness?

However, there is a danger in adopting this conception. Insistence on equality before the law tends outwardly to promote fair processes but can sideline fair substantive outcomes. ${ }^{99}$ This is true even of international law: "While existing human rights conventions provide general protection to all persons, and as a consequence also protect persons with disabilities, these conventions have generally had limited success at ensuring persons with disabilities can exercise their rights." ${ }^{100}$ In this way, equality before the law "is not a guarantee of equal justice." 101 This conception of access to justice was adopted by the New Zealand state party in its response to the list of issues raised by the UN CRPD Committee. It was clearly deficient in the context of the CRPD, which is a specific response to the deficiencies of this very conception. The government also responded in terms more suitable to Article 12 of the convention equal recognition before the law, including "the right to recognition everywhere as persons before the law" 102 - rather than Article 13, which deals with effective access to justice.

Acclaim Otago raised very specific concerns, but essentially the claims were that existing mechanisms were not operating correctly; people with disabilities could not access evidence or lawyers despite an ostensible right to rely on them; no data was being kept about how the mechanisms were operating; and there was no means to enforce any protections given by statute so they were of no practical use. The essential criticism was that "equality before the law" in a negative sense of non-

94 Rebecca L Sandefur, "The Fulcrum Point of Equal Access to Justice: Legal and Nonlegal Institutions of Remedy" (2009) 42 Loyola of LA L Rev 949 at 951.

95 Sackville, supra note 2 at 86. See generally Ronald Dworkin, Taking Rights Seriously (Cambridge, MA: Harvard University Press, 1977); Ronald Dworkin, Law's Empire (Cambridge, MA: Belknap Press, 1986).

96 Martin Partington, "The Relationship between Law Reform and Access to Justice: A Case Study - The Renting Homes Project” (2005) 23 Windsor YB Access Just 375 at 376.

97 Marco Segatti "Access to Justice as a Human Right: Entitlements, Rights and Capabilities in the Legal Process" (unpublished JSD paper, University of Chicago Law School) at 12.

98 Ibid at $12-13$.

99 See Friedman, supra note 1 at 4.

100 Harpur, supra note 53 at 4.

101 Justice Robert French, "Equal Justice and Cultural Diversity: The General Meets the Particular" (2015) 24 Journal of Judicial Administration 199 at 199, 206.

102 CRPD, supra note 6, art 12(1). 
interference was leading to adverse outcomes. The New Zealand government failed to engage with these claims and simply adopted the first conception by referring to ostensible "equality" before the law:

71. Dispute resolution is provided for under the statutory framework (part 5 of the Accident Compensation Act 2001) and this provides access for all people who wish to apply for a review of a decision made by ACC, including persons with disabilities.

$\ldots$

73. There is no charge to a client in applying for a review or any other alternative dispute resolution process,. [sic] These costs are met by ACC. In addition, clients who have disputes heard at review are usually awarded costs for example, to assist with the costs of advocates or support persons. ...

$\ldots$

76. In making a decision, the reviewer must look at the matter afresh based on the information provided at the review, setting aside ACC policy and procedures, and decide the matter only on the basis of its substantive merits under the Accident Compensation Act 2001 .

77. An applicant who is dissatisfied with the outcome of the review can appeal the decision to the District Court. Questions of law can be appealed to the High Court and then to the Court of Appeal.

78. Each of the parties to the dispute can provide evidence to support their position, including evidence that was not available at the time the ACC decision was made. ${ }^{103}$

One major way in which this is a problem is apparent in the observation that "[a] law of general application may have adverse discriminatory outcomes because of the different circumstances and attributes of those to whom it applies." ${ }^{\text {"104 }}$ A law that criminalizes stealing bread is equal because it applies to everybody, but, in reality, its discriminatory effect on the hungry but poor is obvious. Much has been written about this in the critical jurisprudence field. ${ }^{105}$ One study - the largest study ever of unmet legal need - should suffice as an illustration. It measured "finalization" rates (how often the litigation was concluded), finding that "[p]eople with a disability constituted the only disadvantaged group that had lower finalisation levels in most jurisdictions [of Australia]."106 This supported its finding that "social exclusion drives much of the experience of legal problems." 107 In short, thinking of access to justice as being equivalent to, or underpinned by, equality before the law overlooks that certain laws will

103 We have included selected extracts due to space constraints, but the full response is available and readers are encouraged to consider it for themselves.

104 French, supra note 101 at 199.

105 See, e g, Douglas Hay Albion's Fatal Tree: Crime and Society in Eighteenth-Century England (London: A. Lane, 1975), ch 1; Edward Palmer Thompson, Whigs and Hunters: The Origin of the Black Act (Harmondsworth: Penguin, 1977).

106 LAW Survey, supra note 66 at xxiii.

107 Ibid at 26. 
have a special kind of impact on one's life, which they will not necessarily have on the lives of others. ${ }^{108}$ While people with disabilities are "equal before the law" in a highly limited sense, it appears that they are not being treated equally or given equal opportunities.

One implication of this criticism of the first conception is that meaningful "access to justice" needs to deliberately take into account "the specific needs and differences between people and their lived experiences in order to treat those people as equals." ${ }^{109}$ This was the driving force behind the CRPD: the continued experience of people with disabilities emphasizes that this first conception of access to justice does not guarantee nor produce justice in a wider sense. ${ }^{110}$ The convention emphasizes that peoples' experience of disability is often a product of society as much as any particular impairment. As a study of peoples' perceptions of access to justice put it, "it is clear that an accessible justice system must be one that understands and can embrace the importance of social context for those who use it." 111 So while equality is important, it will not be achieved by equating it to the separate concept of access to justice. Within New Zealand's personal injury system, equality before the law is provided for by statutory rights of review and appeal. These have not resulted in access to justice, however. ${ }^{112}$

Persons whose disabilities are caused by accident are required to enter a dispute resolution process against a large state institution. One side is well funded and has an advanced system for obtaining medical evidence and has a large group of expert lawyers. The other is a person who is dealing with the effects of their injuries and, in a best case scenario, has had their income cut by 20 percent, receiving only 80 percent of their pre-accident earnings in accordance with the provisions of the statutory scheme. ${ }^{113}$ In the more likely scenario, claimants are disputing a decision by ACC to suspend their entitlement to weekly compensation, meaning that one party has no income whatsoever as a direct result of the other, more powerful, party's behaviour. Without the resources to gain access to legal representation, access to the law, and access to evidence, injured people have not been able to access justice according to the first conception of access to justice. This stands in stark contrast to the ostensible "access to justice" provided by equality before the law relied upon by the New Zealand government under the first conception.

The first conception overlooks substantive imbalances in power, experience, and expertise between claimants and ACC. ACC is a party to every dispute under the accident compensation system. It has systems and employees trained and resourced for that purpose. There is slowly increasing recognition of this fact by the government ${ }^{114}$ and the courts themselves ${ }^{115}$ in New Zealand's personal injury disputes. The shortcomings of the first conception are illustrated by the deficiencies in legal aid - the legal aid that is technically available does not provide for access to justice for ACC cases. In New Zealand, civil

\footnotetext{
108 French, supra note 101 at 200-201.

109 Trevor CW Farrow "What Is Access to Justice?” (2014) 51 Osgoode Hall LJ 957 at 980.

110 Harpur, supra note 53.

111 Farrow, supra note 109 at 980.

112 Acclaim Otago, "Understanding the Problem," supra note 4; UN Concluding Observations, supra note 44.

1132001 Act, supra note 5, Sch 1, Part 2, cl 30-53.

114 Which recently announced that an independent review would be undertaken by Miriam Dean, QC.

115 Public submissions collated by Ministry for Business, Innovation and Employment, supra note 49, submission of the Chief District Court Judge on the proposal to establish the Accident Compensation Tribunal.
} 
legal aid is usually a loan that must be repaid. ${ }^{116}$ The most lucrative result financially from a dispute with ACC concerns matters of entitlement to weekly compensation and perhaps interest on that figure. ${ }^{117}$ Even if that total sum is substantial, the legal aid system means a claimant must still pay for the privilege of their statutory entitlements. There is no consequent burden on ACC, which is entitled to treat its legal costs like any other administrative cost. Nationwide, the total number of legal aid applications for people challenging ACC's decisions is low. ${ }^{118}$ In the fourteen months from October 2010 to December 2011, there were 140 ACC proceedings funded by legal aid out of a potential pool of around 10,000 reviews and appeals. ${ }^{119}$

In our 2015 review of more than 500 judicial decisions under the ACC dispute resolution provisions, ACC was represented in every case by one of a small group of mainly senior, experienced, specialist lawyers who are frequently involved in litigation. ${ }^{120}$ This compares to the fact that most injured people who are challenging the decision at review or appeal are not being represented by lawyers, ${ }^{121}$ a clear indication that legal aid is too cumbersome to facilitate access to representation in the way implied by the state. The New Zealand experience is that creating statutory rights to challenge ACC in review and appeal does little to allow persons with disabilities to access those rights. In New Zealand, the first conception of access to justice is ineffective even though it has dominated official responses to access to justice concerns in this area.

\section{B. The Second Conception: The Multifactorial Conception of Access to Justice}

The second conception of access to justice as we see it is all-inclusive. We address it here because it embraces responses to the first conception as well as incorporating the lessons of the third and fourth within it. The key to this conception is that "access to justice encompasses a wide range of legal and non-legal pathways to resolving legal problems," $" 122$ although it does not necessarily limit its recognition of "problems" solely to those recognized in law. For example, it questions the substantive justice of the law in a way that the separation of powers doctrine generally prevents a court from doing. Our thesis is that the second conception reflects the CRPD. It is also a more accurate reflection of New Zealand's modern personal injury system, and we accordingly argue it should be the conception adopted in potential reform. The key point of contrast between the second conception, on the one hand, and the third and fourth conceptions, on the other, is that the third and fourth conceptions respectively emphasize the "extra-judicial" or non-judicial aspects of access to justice and the "judicial" or legalistic components of the all-encompassing second conception.

Because of its comprehensive nature, access to justice under the second conception requires disparate criteria to be present. It is not easy to define comprehensively because it embraces any legal mechanism or institution and may also draw on the third conception in rejecting those mechanisms as being

116 Legal Services Act, 2011 No 4, ss 18, 20-21.

$117 E \mathrm{~g}$, reviews and appeals about weekly compensation and interest arise from decisions made by the ACC under the 2001 Act, supra note 5, ss 103, 112, 114, 117.

118 Acclaim Otago, "Understanding the Problem," supra note 4 at 135.

119 Ministry of Justice, "Consultation Paper: New Fees Framework for Civil (ACC) Legal Aid Providers," (2012) at 8.

120 Acclaim Otago, "Understanding the Problem," supra note 4 at 129-136.

121 Ibid.

122 LAW Survey, supra note 66 at $46-47$. 
themselves causative of justice problems. ${ }^{123}$ The second conception is perhaps more easily defined by what it is not. Although it includes the first conception's emphasis on equality before the law for all people, it is defined by its rejection of any restrictive account of the first conception in the same way that the $C R P D$ augments the deficiencies of previous human rights instruments.

The second conception embraces the use of judicial pathways to justice but includes responses to the deficiencies of the first conception. For example, it includes having the right to be heard and informed, ${ }^{124}$ actually being furnished with the information that is required, ${ }^{125}$ access to legal aid, affordable cost, and comprehensible procedural requirements of the court process, and dealing appropriately with self-represented litigants. ${ }^{126}$ In addition, the non-judicial components of access to justice under this conception include the ability to easily identify and access the appropriate, highquality legal services that are needed, ${ }^{127}$ or services in other areas such as health, ${ }^{128}$ as well as being treated with dignity, ${ }^{129}$ being given appropriate referrals by courts to other resources or services, ${ }^{130}$ and ensuring physical access to institutional facilities such as courthouse buildings regardless of impairment. 131

This conception is remarkably broad when considered from the perspective of the first conception. It includes, for example, better access to the process of creating law through the democratic process and the need to collect and monitor data on the outcomes and experiences for disadvantaged groups, such as people with disabilities who are disproportionately disadvantaged by first conception-style reforms. It reflects the holistic disability rights paradigm discussed by Harpur ${ }^{132}$ and the limits on the social model of disability noted by authors such as Tom Shakespeare, ${ }^{133}$ which fails to account for the sometimes unavoidable effects of some impairments (without necessarily casting those impairments negatively). This second conception would account for the end state of the access to justice road described by Canada's National Action Committee in its 2013 report. ${ }^{134}$

One difficulty with adopting this conception of access to justice is strategic. Because it covers so much ground, those who seek to resist access-to-justice reforms can argue that the presence of a small number of the features of this kind of access to justice shows that there are no problems with access to justice. Alternatively, it might be argued that the state can only take so much responsibility for access to justice without dictating substantive outcomes, meaning its responsibilities are limited to negative rights

123 See generally Macdonald, “Access to Justice and Law Reform,” supra note 3.

124 Australian Human Rights Commission, supra note 69 at 9.

125 Canadian Forum on Civil Justice, supra note 65 at 2.

126 See Helen Thompson \& Anna Chalton, "Equal Justice Project" (paper presented to the Equal Justice Project Outreach Symposium "Access to Justice: Is It in the budget?," 6 October 2014) at 2-16. For recent scholarship on self-represented litigants' experience with the justice system, see Bridgette Toy-Cronin, “Keeping up Appearances: Accessing New

Zealand's Civil Courts as a Litigant in Person" (PhD dissertation, University of Otago, 2015).

Australian Human Rights Commission, supra note 69 at 77.

128 LAW Survey, supra note 66 at 19.

129 Australian Human Rights Commission, supra note 69 at 9.

130 Thompson \& Chalton, supra note 126.

131 UK Council on Tribunals, "Making Tribunals Accessible to Disabled People" (November 2002) at 31-35.

132 Harpur, supra note 53

133 Shakespeare, supra note 54.

134 Roadmap for Change, supra note 85. 
of non-interference and a "best efforts"-style compliance regime. The second conception of access to justice more strongly equates "access to justice" with capital J "Justice" and, thereby, puts access-tojustice reforms in with the general socio-political debate over how society's resources should be allocated.

Such arguments have been deployed in the ACC jurisdiction. For example, counsel for ACC in the authors' litigation experience has suggested that the right to effective access to justice in Article 13 of the CRPD was provided for by first conception-style appeal rights and that the "access" was really directed at "accessibility," such as ramps to the courtroom. Most obviously, this argument overlooked Article 9, which is directed at accessibility of that kind and is a separate substantive right. More obviously, however, the argument stems from an understanding that the state can only be responsible for determinants of access to justice, rather than access to justice itself. This small example reveals the strategic weakness in this second conception when a reductive approach is adopted.

We now address the third and fourth conceptions, which can be seen as subsets of the second conception, which respectively emphasize the extra-legal and legal nature of access to justice, before turning to our conclusion.

\section{The Third Conception: Society, Not Law, is Where Justice Lies}

The third dominantly non-legal conception of access to justice goes by the motto that "society, not law, is where justice truly resides." 135 In this way, it is able to withstand the criticism levelled against the first conception; the third conception does look at disparities and difficulties faced by individuals and groups and uses these features to measure people's ability to access justice. The third conception emphasizes that much of an individual's experience of justice does not necessarily correspond with the way that law categorizes, limits, or creates boundaries around the wide variety of interpersonal disputes that occur regularly in society. ${ }^{136}$

One rationale for the third conception is the extensive body of research showing that "[t]he most significant concerns about justice felt by [people] have little to do with legal rights." 137 It also appears to come from disillusionment with the lack of successful reform; as one study asked, "given the efforts made to reform the law to assist people with disabilities before the courts - why are the outcomes described by community members so often unsatisfactory? Is it still the law? Or is it something else?"138 Consequently, this conception of access to justice says social problems are the biggest barrier to access to justice, including "disengage[ment] from the hard work of building a more just society." "139 Although the purpose of this article is not to consider the best ways of improving access to justice, considering the

\footnotetext{
135 Roderick Macdonald, “Access to Justice and Law Reform \#2” (2001) 19 Windsor YB Access Just 317 at 318 [Macdonald, "Access to Justice and Law Reform \#2”].

136 In this way, the third conception shares a pedigree with the prominent pieces in socio-legal studies. See, $e g$, David Engel, "The Oven Bird's Song: Insiders, Outsiders, and Personal Injuries in an American Community" 18:4 Law \& Society Review 551; William LF Felstiner, R Abel \& A Sarat, "The Emergence and Transformation of Disputes: Naming, Blaming, Claiming” 15:3-4 Law \& Society Review 631. Macdonald, “Access to Justice and Law Reform \#2," supra note 135 at 323. See Sandefur, supra note 94 at 950,953 ; LAW Survey, supra note 66 at xvi.

138 Australian Human Rights Commission, supra note 69 at 21.

139 Macdonald, “Access to Justice and Law Reform \#2," supra note 135 at 325.
} 
solutions proposed by this school of thought does help to understand the nature of the third conception. Unsurprisingly, this school of thought argues that the solutions to problems with access to justice must also be non-legal. The ideas for reform therefore include: "[R]e-orientation in the way we think about conflicts, rights, adjudication and all-or-nothing remedies," 140 ensuring the law is "designed and enforced as non-coercively as possible," $"$ and addressing what drives conflict in the first place. ${ }^{142}$

The third conception owes much to Macdonald's seminal writing after he had led a working group on access to justice in Canada. ${ }^{143}$ He made a strong statement of what we would ascribe to the third conception of access to justice, which illustrates the key distinction between the third and fourth conceptions as we see them. Macdonald persuasively criticized lawyers' inability to consider that access to justice could amount to anything except (1) better access to legal institutions and (2) better access to legal professionals to navigate those institutions. ${ }^{144} \mathrm{He}$ argued that scholarship suffered from a "meta phenomenon" in law that created a "false separation of means and ends" "145 and, as a consequence, led to a "displacement of scholarly and political interest: ... first, from justice to law; and then, from law to access to justice; and most recently, from access to justice to access to law." ${ }^{146}$ He stated that current access to justice thinking is derived from an "ethic of legalism," which predicates access to justice as being limited to access to law, without including an assessment of the substantive justice of law in relation to peoples' expectations of justice in an individual situation. ${ }^{147}$ As a result, "access to justice is the access of a disembodied individual to the institutions of formal law, when the latter are seen only as instruments for enforcing pre-established 'just' rights and claims." ${ }^{148}$ He notes that the ethic of legalism means the scope of conceivable solutions to access to justice problems becomes artificially limited: "[A]11 these physical barriers do not speak to the content of justice, or even to its direct achievement, but rather to the structural management of the institutions by which the state legal system purveys its version of justice." 149

Macdonald's key thesis was that converting the pursuit of justice into the application of law has inevitable consequences for access-to-justice thinking and for attempts to mitigate access-to-justice barriers: "Not only is law complex, but its very structure demands lawyers and courts to unravel personal problems. ... [J] ustice, in its transformation into justice according to law operates to generate an unnecessary complexity."

\footnotetext{
140 Ibid at $318,323$.

141 Sackville, supra note 2 at $87, \mathrm{n} 7$.

142 See Larissa Christensen, Stefanie Sharman \& Martine Powell, "Professionals' Views on Child Sexual Abuse Attrition Rates" (2015) 22 Psychiatry, Psychology and Law 542, albeit in the criminal context of child sexual abuse, for good examples of motivations that are not narrowly legal, including fear of being blamed and judged by others, being disbelieved, threats by perpetrators, and the caregiver's relationship to the perpetrator.

143 Macdonald, "Access to Justice and Law Reform," supra note 3.

144 Ibid at 314.

145 Ibid at 289.

146 Ibid.

147 Ibid at 294.

148 Ibid at 298.

149 Ibid at 300.

150 Ibid at 301-302
} 
institutions, ${ }^{151}$ but he does illustrate how there are unavoidable consequences of adopting the ethic of legalism that we ascribe to the fourth conception. We suggest his description of those consequences now perfectly describes many peoples' experience with the ACC scheme: ${ }^{152}$

Rule-following, in the sense of relating sense-data and emotions only to categories postulated by rules and then describing and evaluating conduct only by reference to the vocabulary of these rules assures that responsibility for the achievement of true justice can be parcelled out to individuals performing institutionally defined roles. Lawyers, jurors, and judges all have a role to play in ensuring fidelity to the dictates of rules. None has a responsibility for ensuring that substantive justice results. On this view, legalism is the ineluctable consequence of statism [casting justice in the form of general state-wide law]. ... the achievement of legal justice is reduced to the following of recipes by actors who have been delegated specific roles in the dominating institutional order ... the business of access to justice becomes the business of ensuring that everyone has an equal opportunity to set in motion the institutional structure which permits designated actors to play their defined roles. ${ }^{153}$

The third and fourth conceptions of access to justice interact and resonate in New Zealand's ACC context. The accident compensation system can be seen as an attempt to provide a non-judicial scheme according to the third conception for compensating for personal injury as a response to deficiencies in the court process according to the fourth conception, due to the unsatisfactory outcomes it has generated at a social and individual level. ${ }^{154}$ In Macdonald's terminology, it was an attempt at "dejudicialisation and de-institutionalising disputes" - the Woodhouse scheme can be seen as adopting "the idea that law (and in particular legislation as a form of law) could be deployed to obviate the need for recourse to institutions which sharpen conflict into disputes." ${ }^{255}$ Essentially, the scheme sought to redirect "disputes" from the tort system to external institutions, being the Accident Compensation Commission (as it then was) and redefine the content of those disputes by shifting from fault and the content of a duty of care to dealing with the "consequences" of the accident or the injury and the extensive individual discretion in rehabilitation and compensation.

There are aspects of the third conception envisaged by the CRPD, which is consistent with our interpretation of the convention as a comprehensive second conception approach. For example, the $C R P D$ adopts a social conception of disability because it is drafted in view of the failure of other human rights instruments to advance the human rights of people with disabilities. It envisages positive obligations on a state party to uphold the rights of people with disabilities - for example, by listing socio-economic rights such as rights to health (Article 25); habilitation and rehabilitation (Article 26);

151 Ibid at 312.

152 In the words of one respondent, "you have to fight to get anything." Acclaim Otago, "Crying for Help from the Shadows," supra note 67.

153 Macdonald, “Access to Justice and Law Reform,” supra note 3 at 308.

154 Woodhouse Report, supra note 15 at 23.

155 Macdonald, “Access to Justice and Law Reform,” supra note 3 at 321. 
work and employment (Article 27); and standards of living and social protection (Article 28). ${ }^{156}$ Article 31 also imposes an obligation on states to "collect appropriate information, including statistical and research data, to enable them to formulate and implement policies to give effect to" the $C R P D$, including to "assume responsibility for the dissemination of these statistics and ensure their accessibility to persons with disabilities and others."

The CRPD departs from the third conception to the extent that it is a legal instrument itself and relies on legal institutions for its implementation. Proponents of the third conception might conclude that the use of "rights" as a vehicle for justice is a hallmark of the fourth conception - a legalistic approach that requires legal interpretation. But we think the CRPD is more fairly interpreted as a compelling international normative statement of commitment to certain principles. To that extent, it is a framework for debate and implementation of "access to justice as justice," according to the third conception, rather than imposing a single particular outcome on the basis of formal legal reasoning.

We argue that the second and third conceptions suffer from important limitations to the extent that they limit the use of formal legal rules and instruments. There are historic reasons for the pervasive ethic of legalism identified by Macdonald, which is influenced in part by the Western history of liberalism. ${ }^{157}$ There remains a public desire for written rules of publicly available law as a deliberate attempt to enhance individual freedom. The fourth conception of access to justice remains one that features prominently in the public and institutional imagination: the need to have one's day in court. Liberalism arose as a partial response to feudalism, including the absolute reign of the sovereign and the way that this denied property rights and, what we would now call, human rights to individuals. Legalism is, on a best-case understanding, directed towards consistency, accountability, and objectivity, including protection against the state and the whims of individuals holding state power.

In a disability context, we argue that law cannot be so quickly rejected as a means of achieving justice, given that people with disabilities are only beginning to achieve similar rights. An essential objection made by the authors in Acclaim Otago's shadow report to the UN CRPD Committee ${ }^{158}$ was that ACC's review process relies heavily on the exercise of permissive discretion in relation to matters of evidence, ${ }^{159}$ procedure, ${ }^{160}$ and costs awards ${ }^{161}$ by the judicial officers ("reviewers") determining the review application. The effect of this was that people with disabilities remained supplicants to the exercise of a discretion rather than being independent rights holders who are empowered to rely on rules of law to compel a decision maker in a situation where there is legitimate disagreement about matters of procedure or evidence. ${ }^{162}$ To compound the effects of that discretion, the District Court's appellate jurisdiction had repeatedly emphasized that ACC appeals proceed by way of a rehearing of the

\footnotetext{
156 For one assessment of the ACC scheme against these rights, see Acclaim Otago, “Adopting Issues: An Interim Report to the United Nations Committee on the Convention on the Rights of Persons with Disabilities" (2014), online: $<$ http://acclaimotago.org/wp-content/uploads/2014/07/Report_to_UN.pdf $>$.

157 Macdonald, "Access to Justice and Law Reform," supra note $\overline{3}$ at $6-8$.

158 Acclaim Otago, "The Costs of Paradigm Change," supra note 41.

159 Ibid at 3, 10, 20.

160 Ibid at 18.

161 Ibid at 2-3.

162 Ibid at 18.
} 
substantive issue, ${ }^{163}$ and it has declined to undertake any oversight function over the way reviewers are exercising their discretion. ${ }^{164}$ In addition, reviewers were not subject to any identifiable complaints process, and there was no publicized systemic monitoring of how their discretion was being exercised. We have argued elsewhere that this approach has led to some alarming consequences, including the use of standard forms by ACC that were, "even at a casual glance," beyond the authority bestowed on ACC by its governing legislation. ${ }^{165}$

General declarations of rights with the tools to enforce them against public and private power play a crucial role that should not be quickly rejected. People with disabilities remain subject to fundamental human rights breaches. ${ }^{166}$ While individual, investigative justice procedures can be desirable, the reform of non-judicial institutions often improves access to justice for individuals on a case-by-case basis only. Its success heavily depends "upon a clear and close alignment between the goals and motivations of the providers and the immediate practical needs of the users" in particular instances. ${ }^{167}$ This means that lasting systemic improvement is harder to achieve with the second or third conceptions of access to justice. It is useful to keep these limits in mind in setting expectations for the justice system. Bearing in mind the limitations of the third conception as we see them, we turn to the fourth conception.

\section{The Fourth Conception: Improving Access to the Institutions, Mechanisms, and Substance of the Law}

In somewhat stark contrast to the three previous conceptions sits the fourth conception, in which access to justice is mainly about improving the mechanisms and substance of the law as applied by the courts. A good example of this conception is that adopted in Lord Woolf's well-known civil justice reforms, which states that access to justice requires "that the civil justice system should be just in the results it delivers; fair in the way it treats litigants; capable of dealing with cases at reasonable speed and at reasonable cost; and understandable to those who use it."168 This view accepts that "access" is important - the ability to approach or make use of something ${ }^{169}$ - but it emphasizes the legal "justice" in

1632001 Act, supra note 5, s 155(2).

164 For a strong statement of this approach, see Turner v Accident Compensation Corporation, 2015 NZACC 59 at paras $17-$ 18.

165 See Tiho Mijatov, Warren Forster \& Tom Barraclough, "Problems with Access to Law in Personal Injury Disputes" (2016) 27 NZULR 365, for discussion of the ACC167 form litigation in Powell v Accident Compensation Corporation, 2014 NZACC 89.

166 See the New Zealand Ombudsman's recent report on the treatment of Ashley Peacock, whose confinement and seclusion for five years has been labelled as "cruel, inhuman or degrading treatment or punishment for the purpose of the Convention Against Torture." Office of the Ombudsman, "Report on an Unannounced Visit to Tawhirimatea Unit under the Crimes of Torture Act 1989" (4 February 2016) at para 18.

167 Merran Lawler, Jeff Giddings \& Michael Robertson "Opportunities and Limitations in the Provision of Self-Help Legal Resources to Citizens in Need" (2012) 30 Windsor YB Access Just 185 at 226.

168 Sackville, supra note 2 at 87. See also Les Arthur, "Reform of the Civil Justice System: The New Meaning of Justice and the Mitigation of Adversarial Litigation Culture” (2012) 19 Waikato L Rev 160 at 160, for justice as a balance between accuracy of decision, affordability, and timeliness.

169 Australian Productivity Commission, supra note 66 at 74. 
"access to justice" because justice - the righting of wrongs - is the object to which people seek access. $^{170}$

Another critical feature of this conception is that it commits to a more particular position on what content "justice" has, even if that position is somewhat limited, which may explain why it is more often pursued by academics and by governments seeking certain, measurable goals in the agenda for reform. ${ }^{171}$ In refusing to engage with the substantive justice of rules in the "capital J" sense demanded by the third conception, the fourth conception sidesteps some of the tougher political questions about substantive outcomes. Fourth conception proponents, on a liberal democratic model, would respond to criticisms by the third conception by arguing that representative institutions such as the New Zealand Parliament have conclusively defined justice by their use of legal instruments such as primary and delegated legislation, the use of purpose sections, and the inclusion of a tailored official discretion and contextual definition. ${ }^{172}$

Although the fourth conception can be said to commit to a position on the content of "justice," its account of how the legal process achieves justice has been heavily criticized, including by Macdonald as cited above: "There is an important substantive rationality to the very deployment of competing institutions and processes." "173 And this leads to inevitable consequences when discussing "access to justice," such as that access to law is seen as being sufficient to provide access to justice and is exhaustive of legitimate justice demands, access to law is given by access to legal institutions, and access to legal institutions can only be properly gained by access to professional legal services. ${ }^{174}$ The limitation of the fourth conception's account of justice is that it claims neutrality, and, in doing so, it actually suppresses political conflict in a way that has substantive political effects, in the manner described by Marc Galanter, among many other theorists criticizing the idea of "neutral" access-tojustice procedures: "Despite the quest for theoretical purity in the procedural endeavour that liberal theorists have come to call law, we constantly confront the fact that procedure shapes substance.",175

This objection is not fatal so long as we acknowledge that the fourth conception of access to justice does not purport to resolve every legal problem (let alone wider justice problems), but, in our view, this necessarily places such respondents into the second conception's territory: our key argument, then, is that courts cannot do everything and that they cannot exhaust the access-to-justice agenda. What then can the fourth conception offer? Proponents of the fourth conception say justice is a blend of affordability, timeliness, and rectitude - an ability to get to the truth of the matter. ${ }^{176}$ A significant advantage of this commitment is that it is arguably much easier to measure in a quantitative manner, which means it can form an ostensibly solid and relatable basis for public advocacy. The authors' work

170 Ibid at 74.

171 For an illuminating reflection on the effect of the "policy audience" on research, see generally Austin Sarat \& Susan Silbey, "The Pull of the Policy Audience" 10:2-3 Law \& Policy 97.

172 This objection to what we describe as the third conception based on law as a product of representative democracy is acknowledged by Macdonald, "Access to Justice in Canada Today," supra note 7 at 85.

173 Macdonald, “Access to Justice and Law Reform," supra note 3 at 291.

174 Ibid at 304.

175 Galanter, supra note 11; Macdonald, “Access to Justice and Law Reform," supra note 3 at 293.

176 See A Zuckerman, S Chiarloni and P Gottwald, eds, Justice in Crisis: Comparative Dimensions of Civil Procedure (Oxford: Oxford University Press, 1999). 
before the UN CRPD Committee and in the use of the media as a platform for change has relied heavily on measuring access to justice based on these established fourth conception staples.

The Woodhouse Report that preceded the implementation of the ACC scheme in New Zealand also persuasively critiqued the tort system according to the fourth conception where it decried "artificial barriers" or "expensive [and] drawn out" procedural requirements. ${ }^{177}$ More recently, the fourth conception has been seen to have many components: "First, a competent and impartial judiciary; secondly, accessible courts; thirdly, properly administered courts; fourthly, a competent and honest legal profession; fifthly, an effective procedure for getting a case before the courts; sixthly, an effective legal process; seventhly, effective execution; eighthly, affordable justice." ${ }^{178}$ However, reflecting the ethic of legalism adopted by the fourth conception, two characteristics unite all of these features. The first is a commitment to promoting certain, chosen procedural features that together can be called justice. The second is an emphasis on improving access to courts in order to improve access to those chosen features. An advantage to the fourth conception of access to justice is that, in the New Zealand legal system at least, courts remain central to the law and therefore to "justice" and access to it. Even though most disputes do not make it to the courts, the short, but critical, point is that courts are the backstop. ${ }^{179}$ Parties can ultimately bring their disputes before a court or tribunal, the judgment from which is an exercise of state power from the judicial branch. The benefit to the parties in having a controversy quelled in this way is the very function of the courts. It reflects our community's commitment to the rule of law - a right to be governed under rules and the knowledge that those rules will be enforced. ${ }^{180}$ Of course, even the perfect realization of the proceduralist commitments of the fourth conception would not lead to unlimited advantage. Access to justice via access to courts does not always hold true. Consider, for instance, "a world in which everyone who had any claim whatsoever could get a hearing, had inexpensive and convenient access to counsel, and presumably could get his claim resolved in his favour. Would this be a good society?" "181 In most cases, people would not accept that mere access to courts and due procedural rights is a substitute for an ultimately good society, and this illustrates the value of the third conception.

It is telling that this criticism is only one of degree. Short of seeking unlimited access to this kind of justice, this conception accords with empirical studies of what people expect of justice. At the time he was writing, Macdonald emphasized the lack of empirical studies on what the public seek from access to justice. ${ }^{182}$ Arguably, access to justice should mean whatever the public thinks it should, and a recent

177 Woodhouse Report, supra note 15 at 23, 70.

178 Justice Helen Winkelmann, “Access to Justice - Who Needs Lawyers?” (Ethel Benjamin Commemorative Address 2014, University of Otago, Dunedin, 7 November 2014) at 3, n 3, citing Lord Neuberger's definition (reprinted (2014) 13

Otago L Rev 229).

179 Australian Productivity Commission, supra note 66 at 75, citing the Law Society of Western Australia. See also Winkelmann, supra note 178 at 7 (appropriate to resolve disputes outside the courtroom only if that can be done in a way that roughly reflects their rights and obligations, but that is often not possible especially for the already vulnerable).

180 See PA Keane "Access to Justice and Other Shibboleths" (paper presented to JCA Colloquium, Melbourne, 10 October 2009).

181 Friedman, supra note 1 at 7.

182 Macdonald, "Access to Justice and Law Reform," supra note 3 at 302 (although he did not resile from his comments in a later article other than to suggest the limits of public legal education, for the very fact that "legal information 
survey showed the general public recognized the important role courts play in any conception of access to justice. ${ }^{183}$ Survey data of over 600 injured people indicate that, while there was a strong sense of injustice resulting from treatment by ACC, there was also a strong expectation that such treatment would be investigated and cured by a proper look from a competent judicial authority. ${ }^{184}$

A final feature worth emphasizing is the way we believe this conception must work in New Zealand's personal injury system in a disability context. ${ }^{185}$ Legislation and the words of the CRPD require interpretation. The words used in the text of the CRPD are given meaning by the social context in which they are read. ${ }^{186} \mathrm{~A}$ key deficiency of previous human rights instruments is that they have been read restrictively to avoid requirements to uphold human rights for people with disabilities. ${ }^{187}$ Teodor Mladenov, Harpur, and Macdonald therefore agree that, in terms of access to justice or disability rights, social context will shape the interpretation of text by formal and non-formal institutions. ${ }^{188}$ This context must therefore include the input of people with disabilities:

To the extent that legal rules can be both implicit ... [and] subject to reformulation in the very process of their application - then access to the formal institutions of disputing cannot be exhaustive of the access to justice agenda. ... It follows that access to justice implies equal access to these institutional roles, an equal capacity to generate the implicit and inferential norms into which the recipes of formal law are embedded. ${ }^{189}$

This is also true of the accident compensation legislation and other legislation dealing with personal injury in New Zealand. An effective means of ensuring people with disabilities can influence the meaning of the text of legal documents is by ensuring access to the courts and to the resources to make a persuasive and cogent argument with full appreciation of the consequences of any proposed interpretative approach. ${ }^{190}$

\section{E. Summary and Limitations of the Four Conceptions}

By way of summary, we here include the previous summation of the four conceptions, before applying them to the personal injury system: (1) access to justice as a synonym for equality or nondiscrimination before the law in the manner of earlier human rights conventions; (2) a multi-factorial and wide account of access to justice that includes legal and non-legal formal institutions as well as

programmes typically co-opt the public into thinking that it cannot obtain justice without the aid of lawyers, judges and official law"). Macdonald, "Access to Justice and Law Reform \#2," supra note 135 at 318.

Farrow, supra note 109 at $968 \mathrm{ff}$.

Acclaim Otago, "Crying for Help from the Shadows," supra note 67.

Mladenov, supra note 50.

For an excellent account of this anti-foundational thinking, see generally Michael Robertson, Stanley Fish on Philosophy, Politics and Law (London: Cambridge University Press, 2014).

Harpur, supra note 53 at 5.

Mladenov, supra note 50; Harpur, supra note 53; Macdonald, “Access to Justice and Law Reform," supra note 3 at 309.

Macdonald, “Access to Justice and Law Reform," supra note 3 at 309.

For completeness, we note that Acclaim Otago unsuccessfully applied for leave to intervene in a case before the New

Zealand Court of Appeal. See Hawke v Accident Compensation Corporation, 2014 NZCA 552. 
informal institutions such as community organizations, disabled peoples' organizations, and even the application of accepted or contested norms of social justice; (3) a version that rejects courts as creators and resolvers of disputes, reflecting their perceived failure to dispense justice and therefore emphasizing non-legal institutions; and (4) a version that takes law as justice and regards access to law as access to justice, therefore regarding the courts as justice institutions essential to the application of legal rules and the dispensation of justice.

We again emphasize that we do not intend the conceptions be used in an exclusive or absolute way in the manner of a formal taxonomy. That is a limitation, and we leave it to readers to draw conclusions as to whether the limitation has positive or negative effects. There is one limitation we wish to address here to facilitate future debate. The way our conceptions have been organized means that, to an extent, there may be little with which to disagree. Our conceptions highlight divisions between the kinds of access-tojustice thinking. The most significant division is between the first and second conceptions, and this division is historical and conceptual. Indeed, the history of access to justice is a history of the idea that the first conception alone will not suffice; few access-to-justice scholars would argue that bare appeal rights and the recognition of personhood or equality before the law is sufficient. The first conception is contrasted with the second. Our statement of the second conception embraces the nuanced and intelligent use of every kind of access-to-justice thinking and every tool in the access-to-justice toolbox (including the first, third, and fourth conceptions). Accordingly, it is less of a subset of access-to-justice thinking and more of a statement of the entire set. There can be little disagreement with the content of a category that includes everything within the system that can be categorized.

Further, if the third and fourth conceptions are subsets of the all-encompassing second conception and are distinguished primarily by their orientation towards or away from the use of orthodox legal tools (Macdonald's ethic of legalism), the only disagreement with those conceptions can be where the line is drawn between them, and such line drawing requires a particular example. Such a line cannot be easily drawn; instead, the mere recognition that there may be two ways of thinking is valuable because it does distinguish between different ideas or approaches in access-to-justice thinking historically or conceptually.

Bearing in mind these limitations, the conceptions' utility, then, lies in the fact that they emphasize that there are different ways of thinking about access to justice and by the creation of a shorthand by which to affix labels to particular examples or policy suggestions. Most obviously, we can point to any suggestion by a state that bare appeal rights provide access to justice, name it as the first conception, and emphasize that international law requires a model based on the second conception. Another obvious example is to use the third and fourth conceptions in response to a policy proposal - for example, to inject more alternative dispute resolution into a judicial process. Once a dispute is governed by the application of law or legal institutions to a human relationship, we have usually departed from the third conception, even though the overall motivation might be to "de-judicialize" a dispute.

We would therefore argue that such a process still requires legal advice for people to be properly aware of their legal rights. That can again be contrasted with initiatives such as restorative justice, which are directed at facilitating empathy and understanding between people involved in disputes, on the basis of social norms, which would more accurately be attributed to the third conception. Our own experience has been that these conceptions constitute a useful shorthand for distinguishing between different kinds 
of "access to justice" and stimulating closer attention to be paid to the kind of access to justice that any particular policy seeks to facilitate at any one time within a broader system.

\section{USING THE CONCEPTIONS TO BETTER UNDERSTAND NEW ZEALAND'S PERSONAL INJURY SYSTEM}

We now seek to demonstrate how we have come to use the four conceptions to describe New Zealand's personal injury system in a way that generates greater clarity in the pursuit of "access to justice." We offer the following examples for discussion.

\section{A. ACC's Shift from the Third to the Fourth Conception, and the ACC Tribunal Proposal}

First, we believe that the ACC scheme itself (as narrowly understood) and ACC itself can be said to have reoriented from the third conception, envisaged by Woodhouse and embodied in aspects of earlier statutes, to a fourth conception in the way that the current statute determines cover and entitlements and ACC approaches cover and entitlements. In New Zealand, the tort system (as augmented by workers' compensation schemes and the public health system) operates largely according to the first conception. Anybody with a legally cognisable claim could sue anyone else for causing personal injury. Woodhouse noted there were a series of calls for attention to the failure of this system to deal with the socioeconomic problem of personal injury. With his Royal Commission, he argued that a first conception approach to access to justice for victims of personal injury had failed, and he did so according to the third and fourth conceptions. Third conception concerns related to the fact that, even in a system of perfect access, the justice the system provided was deficient.

For example, the system was not providing just rehabilitation, compensation, or entitlements; the system had counterintuitive results between plaintiffs and did not allocate according to need; each person in society was an asset that should be protected, and it would be better for society as a whole if the effects of accidents on the community were minimized; and the fault principle was not consonant with community expectations. Fourth conception concerns included the fact that the process for achieving justice was civil litigation, which was described as a lottery due to the role of juries and the role of legal counsel; that the delay in bringing a civil claim was extensive and delayed access to remedies; and that the costs of accessing the system were such that very little of the compensation recovered was retained by the plaintiff after the fees of lawyers and experts, meaning that the cost of bringing a claim was undue, if not prohibitive.

The perceived failure of New Zealand's personal injury system to provide access to justice prompted the Woodhouse Report to devise a system that would seek to provide justice directly, with as little formal legal intervention as possible. The test for cover revolved around the low standard of "consequence," and the consequences could arise from the injury or from the accident. ${ }^{191}$ By contrast with the closely prescribed entitlements under the 2001 Act, the only sections that described rehabilitation entitlements in the 1982 legislation were sections 36 and 37, which essentially granted an

191 Judge, supra note 33; Borrows, "Further Improvements to Tribunals Announced," supra note 34. 
open-ended discretion to ACC as an expert organization to deal with need as it saw fit. ${ }^{192}$ Woodhouse recommended displacing the judiciary entirely in matters of personal injury, and, where it was required to intervene in disputes over the system, it was to be as informal as possible. ACC was to remove disputes from narrow legal determination. The corporation itself has been held to be immune from prosecution in negligence or breach of statutory duty, emphasizing the non-legal nature of its duties and the self-contained dispute resolution process. ${ }^{193}$ The idealism was such that, even some twenty years later, leading scholars have said of New Zealand's approach to personal injury: "[T]he corrective justice analysis that an individual whose autonomy has been invaded ought to have it restored and paid for by the person who caused it holds no sway.",194

For whatever reason, ACC's attitude to its own duties under the Act, and the government's policy approach to ACC, has become far more legalistic. ${ }^{195}$ It has become a formal legal institution complete with adversarial processes for obtaining evidence, the application of inherently disputable legal tests, and the jurisdictional issues that limit the possibility for claimants to dispute ACC's actions. Our own observation is that ACC has spent decades progressively fulfilling many of Galanter's criteria for a repeat player in litigation. ${ }^{196}$ Woodhouse's insight was not to abolish fault, but rather to abolish legalism as a means of accessing justice in personal injury. That was the success of his reforms. Later introductions of legalism into the scheme have undone that achievement to a large extent. Further, to the extent that the modern scheme still allows for extra-legal access to justice in the manner contemplated by the third conception, there has been a gradual divergence between the justice the public expects from ACC and the justice it is prepared to give according to a restrictive reading of the statute. The situation is such that public trust and confidence can be said to have "hit a new high" at a level of just 61 percent in the year to March 2016, "up from 56 per cent in the previous 12 months." 197

One of Macdonald's key reflections on how the ethic of legalism we attribute to our fourth conception affects the access to justice agenda goes directly to our thesis: "[T]he costs (and not just the benefits) of legalism ... must be confronted directly." 198 In other words, if ACC wishes to adopt a formal, instrumental, institutional, and legal approach to dispensing justice to victims of personal injury, it cannot avoid the need for legal professionals and formal disputing institutions. It is hard to imagine that the government would wish to direct ACC - the internationally renowned personal injury panacea -

192 Chalecki v Accident Compensation Corporation, 2016 NZHC 517; Chalecki v Accident Compensation Corporation, 2015 NZACAA 1.

193 Traynor v Accident Compensation Corporation, 2012 NZHC 2577; Chalecki v Accident Compemsation Corporation, 2001 NZHC 935; Pearce v Accident Compensation Corporation [1991] 5 PRNZ 297; see also Naysmith v Accident Compensation Corporation [2006] 1 NZLR 40 (HC), for an example of a case where a statement of claim was struck out for breach of statutory duty but not struck out in relation to the claim in negligence as the Corporation had acted in a way that it assumed responsibilty to ensure all statutory assistance and then arguably breached that undertaking.

194 Geoffrey Palmer, "New Zealand's Accident Compensation Scheme: Twenty Years On" (1994) 44 UTLJ 223 at 247, cited in Jesse Wall, "No-Fault Compensation and Unlocking Tort Law's 'Reciprocal Normative Embrace"” (2016) 27 NZULR 125 at 125.

195 Judge, supra note 33.

196 Galanter, supra note 11.

197 Hon Nikki Kaye, Minister for ACC, "Trust and Confidence in ACC Hits New High,” New Zealand Government (5 May 2016).

198 Macdonald, “Access to Justice and Law Reform,” supra note 3 at 326. 
towards the fourth conception of access to justice, given the socio-economic effects that some scholars say the fourth conception invites:

The very formality of legal recourses demands a degree of intellectual sophistication, a fund of personal and familial emotional resources, an ability to restate often diffuse and inarticulable hurts and grievances as legal claims, and a capacity to transform a sense of powerlessness about external events ... into a belief that something can be done. Most citizens ... cannot easily marshal such resources, and even when they are obliged to do so by the state ... their reaction is often simply one of wishing to get the process over as quickly as possible ... [Without adequate social and economic resources, the dispute is just one of] life's setbacks, [and] these simply go unremedied as part of the fate (like death) which all human beings must endure. ${ }^{199}$

The ACC tribunal proposal is an example of how policy interventions that ostensibly aim to facilitate access to justice can actually aggravate access-to-justice problems if they are deployed haphazardly or in an unrealistic manner, as they have been. When the government proposed a new tribunal, it appears now that officials saw this as a third conception project. There were optimistic suggestions that claimants would not even require lawyers. The government failed to consider the fact that dispute resolution was being treated as a fourth conception problem by ACC and that the statute had become highly legalistic. The officials therefore failed to consider whether claimants had access to the determinants of a fair fourth conception of access to justice, including access to lawyers, evidence, and legal information. There was a misunderstanding about what was causing delay. There was a failure to consider how ACC was itself creating disputes because of the way it acted as a fourth conception entity according to an ethic of legalism and adversarial litigation. ACC actively advances legal interpretations that limit claimants' ability to access the dispute resolution process prior to ACC ceasing their entitlements. For example, why should claimants only be given access to the dispute resolution process at the point where ACC has ceased their entitlements rather than at an earlier stage ${ }^{200}$ Had the proposal to replace access to the court with access to a tribunal been implemented, there is now widespread agreement that the access-to-justice barriers would have been exacerbated.

\section{B. ACC from "No-Fault" to a "Limited-Fault" Personal Injury System}

Second, the limitations of the ACC scheme as either a third or fourth conception model have led to an outgrowth of mechanisms that offer different kinds of access to different kinds of justice and are designed to facilitate education and prevention or to attribute accountability or blame in matters traditionally covered by personal injury litigation. This phenomenon has been the subject of recent investigation in New Zealand, and we suggest that this investigation is likely to grow. ${ }^{201}$

199 Ibid at 330.

200 See the recent decisions in Splite v Accident Compensation Corporation, 2016 NZCA 302 at paras 47-50, which takes this approach with regard to the vocational independence process.

201 See Wall, supra note 194; Jesse Wall, 'In What Sense Rights? The Code of Patient Rights and Principles of Justice' in M Henaghan \& J Wall, eds, Law, Ethics, and Medicine: Essays in Honour of Peter Skegg (Wellington: Thomson Reuters, 
New Zealand has seen other formal non-court institutions develop to move the system from a no-fault third conception to a limited-fault second conception personal injury system. These institutions have been created by Parliament through statutes, normally in response to a perceived need being identified by society and often involving investigatory powers along with informal dispute resolution tools cumulating in formal, adversarial, fourth conception processes. Many of these have recreated elements of fault, duty of care, and causation, including the test of "reasonable care and skill." These include the Health and Disability Commissioner, ${ }^{202}$ Worksafe, ${ }^{203}$ and the New Zealand Transport Agency. ${ }^{204}$ These institutions and many others investigate fault and provide mechanisms for prevention, education, accountability, and blame.

In this sense, the third conception has failed to live up to its promise. The failure of the non-judicial conception to create (and operate as) a personal injury system saw the rise in the 1980s and 1990s of extra-judicial grievance and oversight mechanisms. These not only entrenched the public perception of access to justice as non-judicial but also triggered a shift back towards the judicial conception of access to justice. Legislative amendment recreated the negligence test of "reasonable care and skill" along with recourse to courts to rectify breaches of this standard. The decisions of the ACC, the Health and Disability Commissioner, the Privacy Commissioner, and the Human Rights Commissioner all provide access to the court or tribunal where less formal attempts to resolve the dispute have failed.

In addition, in relation to a major source of injury in New Zealand - namely, injury arising out of transport - the criminal law test has been lowered to a negligence test of careless driving causing injury. ${ }^{205}$ In all aspects of criminal law, the court's role has also expanded to include "top-up" remedies, which can be provided to victims of personal injury, in addition to their ACC compensation, on a caseby-case basis where fault can be established. ${ }^{206}$ In the personal injury system, access to justice truly is a moving target. As a result, New Zealand's system of accident compensation should more properly be seen as belonging to the second conception, drawing upon a wide range of means to provide access to different kinds of justice. It is more accurately described as a "personal injury system." Rather than seeing ACC as a "policy orphan" that does not quite sit within the wider justice or social welfare systems, we suggest it should be seen as central to both of these systems. ${ }^{207}$ We believe it is no longer correct to speak of a "no-fault system," and New Zealand instead has a system of "limited fault." Nonetheless, there is no system-wide understanding of the roles of the various mechanisms and how they interact nor integration between them. The result is that many injured people fall through the cracks

2016) (forthcoming); Simon Connell, "Justice for Victims of Injury: The Influence of New Zealand's Accident Compensation Scheme on the Civil and Criminal Law" (2012) 25 NZULR 181.

202

Health and Disability Commissioner (Code of Health and Disability Services Consumers' Rights) Regulations, 1996 78, Sch, Right 4(1).

203 Health and Safety at Work Act, 2015 No 70, Part 2 (health and safety duties).

204 Established by the Land Transport Management Act, 2003 118, s 93, which administers the Land Transport Act, 1998 No 110 , ss 8,38 .

205 Land Transport Act, 1998 No 110, ss 8, 38.

206 See Sentencing Act, 2002 No 9, s 32, amended by Parliament following the decision of the Supreme Court of New Zealand in Davies $v$ New Zealand Police, [2009] NZSC 47, which determined that top-ups of accident compensation payments were not possible through the Sentencing Act 2002.

207 Geoffrey Palmer, “'The Nineteen-Seventies': Summary for Presentation to the Accident Compensation Symposium” (2003) 34:2 VUWLR 239 at 246. 
as they try to navigate the system and do not have the ability to obtain satisfactory remedies from any institutions, and no one institution is tasked with substantively just outcomes.

\section{CONCLUSION}

In its shadow report to the UN CRPD Committee, Acclaim Otago concluded in the following terms, which we can now describe as a plea for reform towards a conscious appreciation of the personal injury system within the second conception of access to justice:

There is complete and widespread failure of the existing statutory mechanisms providing access to justice for injured people. There are no effective mechanisms to identify and address systemic problems with the ACC system. The Health and Disability Commission, the Human Rights Commission and the Ombudsman have not been able to effect the necessary changes. The internal ACC complaints process is entirely ineffective and subject to a conflict of interest. This has resulted in widespread systemic failure to protect the $C R P D$ rights of persons with disabilities caused by personal injury in New Zealand. The State does not recognise the application of the CRPD to injured persons with disabilities covered by ACC. ${ }^{208}$

It remains to be seen whether the New Zealand government will respond to this challenge and what conception of access to justice it will adopt for New Zealand's personal injury system.

More transparent transformation of the meaning of access to justice is timely, particularly in light of the recommendations by the UN CRPD Committee and the serious failures of policy that have led to a legislative proposal for an accident compensation tribunal. There is a particular need to avoid interpreting access to justice along the lines of "equality before the law" and the first conception. New Zealand's personal injury system needs to rethink whether either the third or fourth conceptions alone can provide "access to justice." We suggest that they cannot. We conclude that the second, multifactorial conception is a more accurate representation of how ACC should operate within a personal injury system.

The second conception has promise in this area but will require deep understanding and empirical study of how the system operates. It requires constant vigilance to avoid inappropriate or unconscious lapses into the other conceptions. The personal injury system will also require careful scrutiny to ensure positive interactions between the role of the courts and other legal institutions and applying social and human rights models of disability. If we divide our attention, we risk missing the opportunity offered by the multifactorial approach. But, worse, if we refuse to consciously acknowledge the different conceptions at all, we risk missing the meaning of access to justice.

208 Acclaim Otago, "The Costs of Paradigm Change," supra note 41 at 22. 